(C) 2013

\author{
Фесенко О. Г., аспірант
}

(науковий керівник - доктор сільськогосподарських наук, професор П. В. Писаренко)

Полтавська державна аграрна академія

\title{
СТАН ПОВЕРХНЕВИХ ВОД ПОЛТАВСЬКОЇ ОБЛАСТІ (2005-2011 рр.)
}

\section{Рецензент - кандидат сільськогосподарських наук М. А. Піщаленко}

\begin{abstract}
Проблеми якісного $i$ безпечного водопостачання на Полтавщині надто болючі, щзо зумовлено як природними, так і техногенними чинниками. Внаслідок господарської діяльності людини найбільше забруднюється шкідливими речовинами водне середовище. Екологічна ситуачія в Полтавському регіоні має тендениію до ускладнення, яке значною мірою зумовлене проблемами води: спожсиваня води низької якості, використання водоймищ, забруднених недостатньо очищеними і незнезараженими стічними водами. Як відомо, Полтавська область повністю розміщена в басейні Дніпра. В області пращ̧ює 45 підприємств, щзо забруднюють водний басейн.
\end{abstract}

Ключові слова: поверхневі води, контрольні створи, оиінка якості води, комбінаторний індекс забруднення, екологічна ситуація.

Постановка проблеми. Наявність взаємозв'язку господарської діяльності людини 3 оточуючим середовищем та посилення й навіть загострення іï впливу на різні компоненти довкілля, в тому числі й на поверхневі водні об'єкти, наразі ні в кого не викликає сумніву. У цій ситуації безсумнівним також стає факт зростаючої потреби у реагуванні людини на ті зміни, що вже відбуваються у водному середовищі, а також на створення відповідних запобіжних умов та здійснення прогнозування подальших темпів і напрям захисту поверхневих об'єктів.

Для вирішення цих задач необхідним є проведення постійної оцінки динаміки змін у поверхневому водному середовищі й прогресу розвитку суспільства на будь-якому рівні - від локального до глобального - що, у свою чергу, потребує збору й створення значного масиву інформаційних даних стосовно їх взаємозв'язку й впливу на довкілля [3].

Аналіз основних досліджень і публікацій, у яких започатковано розв'язання проблеми. Вода - найпоширеніша неорганічна сполука на планеті. Вона $є$ основною всіх життєвих процесів, єдиним джерелом кисню в головному рушійному процесі на Землі - фотосинтезі.

3 розвитком суспільства проблеми чистої води й охорони водних екосистем стають дедалі все гострішими, поскільки стрімко посилюється вплив на природу, спричинений науково-технічним про- гресом і кліматичними змінами [1].

Особливі труднощі виникають у процесі комплексних оцінок якості вод в умовах багатоцільового використання водного об'єкта. Питання комплексної оцінки якості води вивчалося багатьма вченими не лише в Україні (В. С. Жукинський, Д. В. Закревський, В. І. Пелешенко, В. Д. Романенко, С. І. Сніжко, В. К. Хільчевський, А. П. Чернявська, А. В. Яцик), а й за кордоном (Дж. Браун, О. Труітт, Т. Харкінс). Оцінити якісно та кількісно стан ландшафтів, що знаходяться під впливом людської діяльності, - досить складне завдання, поскільки він (стан) визначається багатьма факторами [4].

Як свідчить аналіз основних літературних даних із проблеми, сучасні методи оцінки забрудненості поверхневих вод розрізняють: за метою використання; принципами розробки; критеріями оцінки; за обсягом та характером наявної інформації [3]. Загальноприйнятого методу оцінки стану поверхневих вод, на жаль, на сьогодні не існує. Тому зі значної кількості таких методів ми обрали ті, що найкраще, на нашу думку, відповідають поставленим цілям і завданням даного дослідження.

Як бачимо, основою для екологічної оцінки стану поверхневих водних джерел за будь-яких із цих підходів є достатньо потужна база вихідних інформаційних даних. Для їх збору та систематизації необхідне проведення постійного моніторингу стану поверхневого водного середовища та умов життедіяльності людей у рамках певної територіальної (регіональної) системи.

Дослідження в цьому напрямі проводилися в межах питання «Покращання екологічного стану річок України на основі Європейської водної рамкової Директиви» згідно 3 проектом Tempus [2]. Означені матеріали підготовлені за фінансової підтримки Європейського Союзу в рамках проекту Тасіс «Управління басейнами річок Буг, Латориця та Уж» Консорціумом компаній RODECOVERSeau - WRc. Розробки, висновки та інтерпретації, представлені у цьому документі, є вираженням поглядів Консорціуму і їх не слід розуміти як такі, що відображають політику 


\section{СТОРІНКА МОЛОДОГО ВЧЕНОГО}

чи думку Європейської Комісії [2]. Крім того використано матеріали із застосування Агроекологічного центру (АЕЦ) у м. Полтава[5].

Мета досліджень. Основною метою даної статті $є$ дослідження загального стану поверхневих водних джерел у районах основних водозаборів комплексного призначення Полтавської області на основі літературних даних.

Завдання досліджень: провести аналіз загального стану поверхневих водних джерел Полтавської області та визначити підприємствазабруднювачі наявного водного басейну.

Методи дослідження. Основним методом досліджень став комбінаторний індекс забруднення (KI3).

Результати досліджень. Застосування показників якості, що відображають основні параметри екологічного стану поверхневих водних об'єктів, набуло свого поширення в світовій науці й практиці в останні $15-20$ років. За цей час сформувалися певні методологічні підходи оцінки стану поверхневих вод та їх класифікація.

За даними літературних даних, найбільш відомими підходами, що використовуються для оцінки стану поверхневих водних джерел, $\epsilon$ такі:

- оцінка якості води за комплексним показником - індексом забрудненості води (I3В), рекомендована для використання підрозділами Держкомгідромету [7];

- оцінка якості води, що базується на критеріях Водної рамкової Директиви СС 2000/60/СС [2];

- оцінка якості води на основі комбінаторного індексу забруднення (КІ3) [6].

Річкова мережа по території Полтавської області рівномірно розвинута. По території області протікає 146 річок загальною довжиною 5101 км. У структурі географічної сітки області одна велика річка (Дніпро, у межах області 145 км), середні річки - Сула (213 км), Удай (129 км), Оржиця (89 км), Псел (350 км), Хорол (241 км), Ворскла (226 км), Мерла (28 км), Оріль (80 км), а також 137 малих річок завдовжки понад 10 км, загальною довжиною 3596 км. Головними джерелами водних ресурсів області є річки Сула, Псел, Ворскла, Оріль та їх притоки, а також Кременчуцьке й Дніпродзержинське водосховища на Дніпрі. У межах області формується стік трьох річок: Сліпорід, Говтва, Тагамлик.

В області нараховується 124 озера, загальною площею водного дзеркала 676 га і загальним об'ємом 7,6 млн м ${ }^{3}$ води. Велике поширення мають заплавні озера: їхні розміри, форма і глибина дуже різні й залежать від їх водності в різні періоди року; багато стариць та відмерлих старих рукавів річок, більше всього їх у заплавах долин річок Сула, Оріль, Ворскла, Псел. Як правило, всі вони річкового походження, мають витягнуту форму і невелику глибину, більшість із них гідрологічно з'єднані з річками, під час весняної повені живляться їх водами.

На річках значне поширення мають штучні водойми - водосховища і ставки, які використовуються для водопостачання, гідроенергетики, зрошення, рибного господарства та інших народногосподарських потреб. Усього на Полтавщині 68 малих водосховищ і 1272 ставки. На півдні та південному заході область прилягає до двох великих водосховищ - Кременчуцького та Дніпродзержинського, повний об'єм яких становить, відповідно, 13520 та 2450 млн м ${ }^{3}$ зрегульованої в них води. Їх площа водного дзеркала в межах області становить 108 тис. гектарів.

Водосховища і ставки утворені для поповнення водності річок у маловодні періоди і накопичення весняних вод, для запобігання наслідків шкідливої дії вод, попередження катастрофічних паводків та повеней на нижче розташовані населені пункти.

За питомою водозабезпеченістю одиниці площі території та кількості поверхневого стоку, який припадає на 1 особу, Полтавщина займає 11-е місце в Україні [9].

Основними водокористувачами-забруднювачами водних об'єктів в області, що здійснюють скидання забруднених стоків, $є$ Полтавський ГЗК, Рижівський гранкар'єр (Гадяцький район), Кременчуцьке кар'єроуправління «Кварц», підприємства Укрзалізниці (станції Гребінка, м. Полтава), комунальні господарства, підприємства харчової промисловості та ін. [8]. Через незавершення робіт із реконструкції та капітального ремонту очисних споруд має місце скид недостатньо очищених стічних вод у поверхневі водні об'єкти області. 3 метою контролю й аналізу стану поверхневих водойм у місцях розміщення очисних споруд проводиться моніторинг та аналіз стану забрудненості водойм відповідними обласними структурами за групами показників [8].

За рівнем біохімічного забруднення вода в найбільших річках класифікується на основі результатів моніторингу, проведеного Всеукраїнською екологічною громадською організацією «MAMA - 86», так: р. Дніпро ( у межах області) - помірно забруднена; р. Сула - забруднена; p. Ворскла - брудна; р. Коломак - забруднена; p. Псел - помірно забруднена; р. Хорол - брудна. Щорічно в області у водні об'єкти скидається близько 110 млн м ${ }^{3}$ стічних вод [9].

Серед методів оцінки якості поверхневих вод виділяють: фізико-хімічні (засновані на індиві- 


\section{СТОРІНКА МОЛОДОГО ВЧЕНОГО}

дуальних і комплексних показниках), біологічні й комбіновані методи.

Для оцінки стану поверхневих вод Полтавської області нами обраний фізико-хімічний метод, оскільки він якнайточніше дає змогу оцінити забруднення води конкретними забруднювачами, враховує сумісний вплив забруднюючих речовин, дає можливість класифікації якості води та характеристики середовища існування водних організмів [8].

Аналіз сучасного екологічного стану водних об'єктів, проведений автором, свідчить, що негативні процеси викидів забруднених відходів у річки й водосховища басейну Дніпра.

Окрім того, більшість річок і водотоків із часом замулилися, заросли болотною рослинністю та чагарниками, втративши своє первинне природне значення. Вони не мають дренуючої спроможності, в результаті чого заплавні землі заболочені й підтоплені, відтак не можуть використовуватися в сільському господарстві.

Передусім така ситуація спостерігається на малих річках, протяжність русел яких на території Полтавщини не перевищує 20-35 кілометрів. Через заболоченість їх русел і заплавних земель не створюються водоохоронні прибережні смуги, що, в свою чергу, призодить до їх незадовільного санітарного та гідромеліоративного стану.

Екологічний стан водних об’єктів Полтавської області за період 2005-2011 років оцінено нами на основі комбінаторного індексу забруднення (KI3) 3 урахуванням 10 показників: хлориди; сульфати; азот амонійний, нітритний i нітратний; фосфор фосфатів; розчинений кисень;
$\mathrm{БCK}_{5}$; залізо загальне; нафтопродукти. Дані для розрахунку КIЗ формувалися на основі даних моніторингу Державного управління охорони навколишнього природного середовища в Полтавській області, Полтавського регіонального управління водних ресурсів, обласного центру 3 гідрометеорології, обласної санітарно-епідеміологічної станції [6].

За результатами оцінювання якості річкових вод Полтавщини, їх рівень забруднення коливається від II класу «забруднена вода» до IV класу - «дуже брудна» (КI3 $=1,9 \div 7,5)$ (див. рис.).

За результатами Державного управління охорони навколишнього природного середовища в Полтавській області, Полтавського регіонального управління водних ресурсів, обласного центру 3 гідрометеорології, обласної санітарно-епідеміологічної станції, якість води в створах Дніпра, Сули, Псла, Ворскли, Хоролу, Сухого Кагамлика переважно відноситься до III класу, тобто кла-

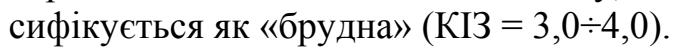

Особливо негативний стан стосовно забруднень характерний у створах більшості малих річок: Крива Руда, Орчик, Суха Лохвиця, Коломак, Багачка, Говтва, Тагамлик, Удай, Татарка, Кобелячок, Сухий Омельник (КІ3 коливається в межах 5,0 7,5). Відповідно, якість води належить до IV класу, тобто «дуже брудна».

За результатами екологічного оцінювання, близько 53 \% від загальної кількості пунктів гідроекологічних досліджень (їх в області 99) за рівнем забруднення класифікуються як «дуже брудні» (IV рівень).

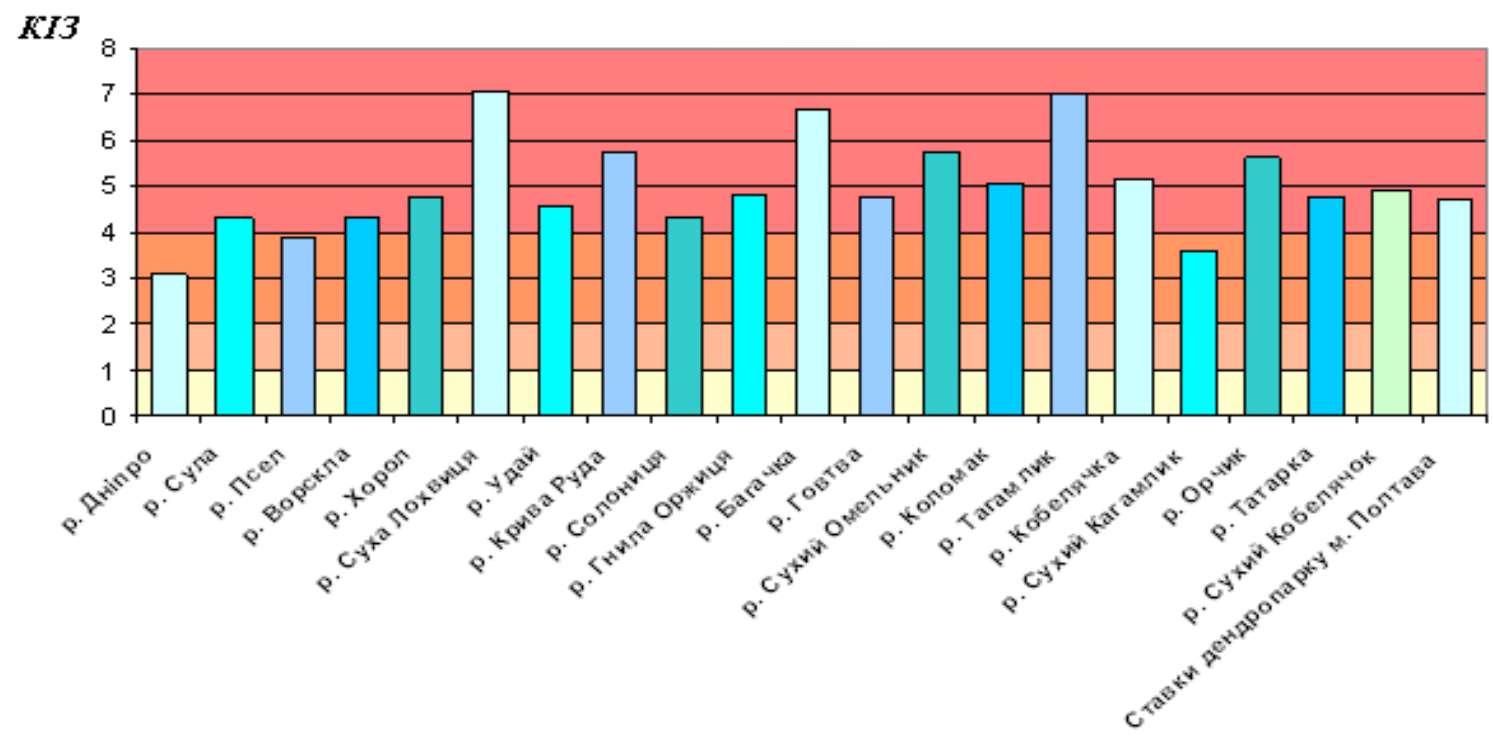

Рис. Результати аналізу стану поверхневих вод Полтавськой області в басейні ріки Дніпро за період 2005-2011 років [6] 


\section{СТОРІНКА МОЛОДОГО ВЧЕНОГО}

До такої категорії водних об’єктів за їх «якістю» належать практично всі малі річки. Лише 4 \% пунктів від загальної їх кількості за рівнем забруднення класифікуються як «забруднені» (II рівень).

Основними причинами погіршання якості води в створах малих річок Крива Руда, Суха Лохвиця, Коломак та інших є недостатня ефективність роботи наявних очисних споруд, незадовільний стан каналізаційних мереж, насосних станцій та споруд зливової каналізації. Зокрема, незадовільно працюють споруди штучної біологічної очистки, коли значна частина води припадає на промислові стічні води, що надходять на каналізаційні очисні споруди без попереднього очищення на локальних очисних спорудах підприємств. Відсутні або мають незадовільний стан каналізаційні мережі та очисні споруди у містах Гадяч, Миргород, Пирятин, Глобино, Гребінка, Зіньків, Лохвиця, Карлівка, смт. В. Багачка, Чорнухи, Козельщина, Градизьк, Котельва, Чутово, Опішня, Семенівка [6].

Як свідчать літературні дані, ситуація щодо якості води на полтавських ділянках двох Дніпровських водосховищ потребує окремого дета-

\section{БІБЛІОГРАФІЯ}

1. Авраменко H. I. Евтрофікаційні процеси річки Ворскла / Н. І. Авраменко // Вісник Полтавської державної аграрної академії. - 2010. - №4. - C. 179-181.

2. Водна рамкова Директива СС 2000/60/ЄC від 23 жовтня. Основні терміни та їх визначення. - K., 2006. -240 c.

3. Голік Ю. С. Оцінка стану поверхневих водних джерел Полтавської області / Ю. С. Голік, О. Е. Ілляш, В. О. Москвич // Экология плюс. - 2009. № 4. - C. 22-32.

4. Мосейчук $A$. А. Оцінка якості питної води в джерелах децентралізованого водопостачання Полтавської області / А. А. Мосейчук, І. А. Бойко // Вісник Полтавської державної аграрної академії. - 2011. - №4. - C. 12-17.

5. Офіційний сайт агро-екологічного центру льного дослідження, а також розробки і здійснення спеціальних заходів, спрямованих на 3'ясування сили, характеру, джерел і чинників процесу евтрофікації Кременчуцького та Дніпродзержинського водосховищ у зв'язку із загрозливою ситуацією в районах питних водозаборів міст Кременчука і Комсомольська [6].

\section{Висновки:}

1. Спостерігається постійне збільшення забруднених поверхневих вод області через потрапляння до них стічних вод промислових підприємств, господарсько-побутових стоків, а також через незадовільну роботу каналізаційних мереж та очисних споруд.

2. 3 метою досліджень поверхневих вод Полтавщини потребує детального аналізу якість води на Дніпровському водосховищі та 3'ясування причин процесу евтрофікації.

3. Для вирішення проблем необхідно залучати представників центральних органів виконавчої влади, науковців, провідних фахівців водної галузі, громадські організації та населення. Лише спільними зусиллями ситуація може бути змінена на краще.

http://www.aec.org.ua.

6. Регіональна цільова програма розвитку водного господарства та екологічного оздоровлення басейну р. Дніпро Полтавської області на період до 2021 р. - Полтава: Полтавський літератор, 2013. $-157 \mathrm{c}$.

7. Сніжко С. I. Оцінка та прогнозування якості природних вод: Підручник. - К. : Ніка-Центр, 2001. $-264 \mathrm{c}$.

8. Степова O. В. Аналіз стану поверхневих вод Полтавської області в контрольних створах / О. В. Степова, Р. В. Булавенко, В. В. Рома // Вісник Полтавської державної аграрної академії. - 2012. - №1. - C. 181-184.

9. Чи безпечна вода на Полтавщині? - Полтава: ПМЕГО « МАМА - 86». - 2010. - 16 с. 